\title{
Introductory Remarks by Burhan Gafoor
}

\author{
Chair of the Sixth Committee of the General Assembly at Its \\ Seventy-Second Session
}

The relationship between the Sixth Committee and the Commission is an organic and symbiotic one. The Sixth Committee has an important role to play and I would like to identify three roles that are important from my point of view. First, it continues to function in the traditional role, of being one of the main Committees of the General Assembly, as a forum for debate, and as a forum for legal matters to be debated by policy makers. This role, which can be called a policy-making role, is manifested ultimately in the draft resolutions adopted by the Sixth Committee. The draft resolutions are a result of very careful, deliberate and wide-ranging consultations and negotiations. There is considerable interaction between representatives of the Sixth Committee and legal advisers from capitals, especially when it comes to discussing the report of the International Law Commission. The Sixth Committee's debate on this particular report is also an occasion that demonstrates the very close relationship between the Commission and the Committee. The interaction is one of the unique features of International Law Week, held during the annual General Assembly sessions. The debate on the report and the negotiation on the resolution are intended to provide clear policy guidance and decisions on matters relating to the work of the Commission.

The second role played by the Committee is as a negotiating forum. Through its working groups and subsidiary bodies, over the years, the Committee has concluded a number of important instruments, including on drafts based on the Commission's works. Indeed, the Convention on the Law of the NonNavigational Uses of International Watercourses ${ }^{1}$ was negotiated in the framework of the Working Group of the whole of the Sixth Committee, on the basis of draft articles prepared by the Commission. ${ }^{2}$ The last time that the Sixth Committee proposed the convening of a diplomatic conference, the traditional form of concluding and adopting such instruments, was with respect to the Rome Conference on the establishment of the International Criminal Court, which was inspired by a text that was prepared by the Commission ${ }^{3}$ and was

1 Adopted 21 May 1997, entered into force 17 August 2014, UNTS registration no. 52106.

2 ILC, 'Draft articles on the law of the non-navigational uses of international watercourses' [1994] II (2) ILC Ybk 89.

3 ILC, 'Draft Statute for an International Criminal Court, with commentaries' [1994] II(2) ILC Ybk 26; 'Draft code of crimes against the peace and security of mankind' [1996] II(2) ILC Ybk 15. 
further the subject of negotiations in the context of ad hoc and preparatory committees established on the recommendation of the Sixth Committee prior to the convening of the Conference.

The third role of the Committee that we have also witnessed is the Committee serving as a filter and consensus builder. For instance, through the use of informal consultations, the Committee has facilitated the reaching of a generally acceptable decision in the case of the draft articles on the status of the diplomatic courier and the diplomatic bag not accompanied by the diplomatic courier. ${ }^{4}$ Today, the Committee continues to utilise modalities such as working groups and informal consultations in order to help build consensus on particular issues.

Over the last 10 to 15 years, the Commission has presented to the Sixth Committee eight completed works, ${ }^{5}$ which remain in the Committee at various levels of discussion. The task that faces the Sixth Committee is to bring these various discussions and processes to a successful closure. To do this, the Committee will have to navigate and address the legal, policy and other considerations in order to build consensus and reach political agreement. This is no easy task, but I believe that by working collectively within the framework of the Committee, and by continuing to perform the role of building consensus and finding political agreement, the Committee can make an important contribution to reaching agreement on some of the most important issues before it. The last thing that I would say is that within the Committee, there is a degree of professionalism and congeniality that I find remarkable. There is a very positive spirit of cooperation that prevails among all members. I think that this too is a very important asset for the work of the Committee as it works together with the Commission to help build consensus on important issues of international law.

4 See UNGA decision 50/416 (11 December 1995) UN Doc A/5o/49 (vol I) 351.

5 These are: (a) ILC, 'Draft articles on responsibility of States for internationally wrongful acts' [2001] II(2) ILC Ybk 26; see also Unga Res 56/83 (12 December 2001), annex; (b) ILC, 'Draft articles on prevention of transboundary harm from hazardous activities' [2001] II(2) ILC Ybk 146; (c) ILC, 'Draft principles on the allocation of loss in the case of transboundary harm arising out of hazardous activities' [2006] II(2) ILC Ybk 58; (d) ILC, 'Draft articles on diplomatic protection' [2006] II(2) ILC Ybk 24; (e) ILC, 'Draft articles on the law of transboundary aquifers' [2008] II(2) ILC Ybk 19; (f) ILC, 'Draft articles on the responsibility of international organizations' [2011] II(2) ILC Ybk 4O; (g) ILC, 'Draft articles on the expulsion of aliens' (2014) UN Doc A/69/10, 11; and (h) ILC, 'Draft articles on the protection of persons in the event of disasters' (2016) UN Doc A/71/10, 13 . 